\title{
Seasonal evaluation of groundwater quality around Igando dumpsites in Lagos metropolis using correlation and regression analysis. *11IDOWU BALOGUN; OLUBUNMI ADEGUN
}

*Senior Lecturer, Department of Geography, University of Lagos, Akoka. E-mail: idowubalogun@yahoo.com. **Doctoral Student, Department of Geography, University of Lagos, Akoka.

Keywords: Groundwater; Dumpsites; Correlation; Regression; Model

\begin{abstract}
Correlation and Multiple linear regression analysis was used to establish the degree of relationship and variability of groundwater quality parameters around Solous 1 and 2 Dumpsites, in Igando, Lagos, for the wet and the dry seasons. The correlation between TDS and other hydrochemical parameters which constituted the independent variables were positive, with significantly high positive correlation exhibited between TDS and EC for the wet season. For the dry season, the correlation between TDS and other groundwater quality parameters $\left(\mathrm{EC}, \mathrm{NO}_{3}{ }^{-}\right.$and $\left.\mathrm{Cl}^{-}\right)$was positive, while its correlation with $\mathrm{Zn}^{2+}$ and $\mathrm{Fe}^{2+}$ was negative. The results of the multiple linear regressions for the wet and the dry seasons indicate that the model accounts for 96.8 percent and 93.9 percent, respectively of the variance of TDS concentration of groundwater around the dumpsites @ JASEM
\end{abstract}

DOI: http://dx.doi.org/10.4314/jasem.v17i2.16

Dumpsites and landfills alike may pose a myriad of environmental problems, the most prominent of which is groundwater contamination. This risk is particularly high for groundwater within and around dumpsites with no leachate control and collection facilities. This situation is however not restricted to dumpsites that lack leachate control facilities, as groundwater around landfills with bottom liners and leachate collection systems are also vulnerable to contamination from leachate especially if there are issues of inadequate design and construction, or problems of maintenance (Bjerg, Albrechtsen, Kjelsen \& Christensen, 2003).

At the Solous dumpsites in the Igando area of Lagos Metropolis, there are no environmental cautionary measures put in place by the Lagos State Waste Management Authority (LAWMA), hence the need for information on the status of groundwater quality around the dumpsites. One of the ways in which this can be achieved is through the characterisation of groundwater quality and the establishment of the degree of relationship among different water quality parameters in order to assist in groundwater quality monitoring and prediction. Due to the multivariate nature of groundwater quality and the need to obtain pertinent information from the available hydrochemical datasets, correlation and multiple linear regression analysis were used as statistical tools for this study.

\section{MATERIALS AND METHODS}

Study Area: Solous 1 and 2 Dumpsites (Fig. 1) are located between $6^{0} 34^{\prime} 17.47^{\prime \prime} \mathrm{N} ; 3^{0} 15^{\prime} 16.93^{\prime \prime} \mathrm{E}$ and $6^{0} 34^{\prime} 13.94^{\prime \prime} \mathrm{N} ; 3^{0} 15^{\prime} 08.94^{\prime \prime} \mathrm{E}$ and between $6^{0}$ $34^{\prime} 19.37^{\prime \prime} \mathrm{N} ; 3^{0} 15^{\prime} 05.96^{\prime \prime} \mathrm{E}$ and $6^{0} 34^{\prime} 15.68^{\prime \prime} \mathrm{N} ; 3^{0}$ $15^{\prime} 01.31^{\prime \prime} \mathrm{E}$, respectively. Both dumpsites are located opposite each other along LASU-Igando road, in the Alimosho Local Government Area of Lagos.
Climate: The climate of Igando and its environs is of the warm tropical type, having little seasonal variation. Mean annual temperature is around $30^{\circ} \mathrm{C}$ with narrow diurnal and annual ranges while humidity is about 75 percent with a steady vapour pressure.

Hydrogeology and Groundwater Supply:Solous dumpsites and environs are made up semi-permeable to impermeable materials of variable thickness. The area's hydrogeological profile is composed of a top layer of lateritic clay and thick strata of clay underlain by fine grained sand. The basal sand and the first aquifer horizon are underlain by clayey sand of extensive thickness.

At Igando, the Solous dumpsites environs in particular, groundwater constitutes the main source of water supply. This is due to the inadequate coverage of the area by the Igando mini-waterworks supply network, and the demand for water outweighing the supply from the mini-waterworks. The inadequate supply of water by the mini-waterworks (which also depends on groundwater) is attributed to its inability to produce at the installed capacity. The mini-water works has an installed capacity of $1.0 \times 10^{6}$ litres/day but is only able to produce $0.4 \times 10^{6}$ litres/day, i.e., $40 \%$ of installed capacity.

Groundwater Sampling and Analytical Methods: In order to determine seasonal variations of groundwater quality in the vicinity of the two dumpsites, fifteen groundwater samples each were collected for the wet and dry seasons, in November, 2010 and March, 2011 respectively. Sampling and analytical procedures of the groundwater were done in accordance with standard methods of water and waste water analysis (APHA, 1992). The analysed hydrochemical parameters include Total Dissolved Solids (TDS), 
Electrical Conductivity (EC), Nitrate $\left(\mathrm{NO}_{3}{ }^{-}\right)$, Chloride $\left(\mathrm{Cl}^{-}\right)$, Zinc $\left(\mathrm{Zn}^{2+}\right)$ and Iron $\left(\mathrm{Fe}^{2+}\right)$. TDS and EC were measured in-situ using $\mathrm{HM}$ Digital EC/TDS/TEMP COM-100 Meter. $\mathrm{Cl}^{-}$was analysed in the laboratory through silver-nitrate titration with potassium chromate as an indicator, while $\mathrm{NO}_{3}{ }^{-}$was analysed using spectronic 20D+. $\mathrm{Zn}^{2+}$ and $\mathrm{Fe}^{2+}$ was analysed using Perkin-Elmer atomic absorption spectrophotometer (AAS).

Statistical Techniques: The correlation and regression analysis module of Statistical Package for the Social Sciences Version 17 (SPSS Inc, 2008) was utilised. For correlation analysis, Pearson's product moment correlation was employed while for the regression analysis, the Simultaneous Method (i.e., the Enter Method in SPSS) of the multiple linear regression was adopted.

Pearson's product moment correlation coefficient is stated as:

$\mathrm{r}=\Sigma \mathrm{xy}$

$\mathrm{N \sigma}_{\mathrm{x}} \sigma_{\mathrm{y}}$

Where

$\mathrm{r}=$ product moment correlation coefficient $\mathrm{x}=(\mathrm{X}-\mathrm{X})$; $\mathrm{y}=(\mathrm{Y}-\mathrm{Y}) ; \sigma_{\mathrm{x}}=$ Standard deviation of series $\mathrm{x} ; \sigma_{\mathrm{y}}=$ Standard deviation of series $\mathrm{y} ; \mathrm{N}=\mathrm{No}$ of pairs of observations.

The multiple linear regression model is stated as:

$Y_{i}=\beta_{0}+\beta_{1} x_{1 i}+\beta_{2} x_{2 i}+-------\beta_{q} x_{q i}+\varepsilon_{i}------------$ (2)

where:

$Y_{i}=$ dependent variable predicted by regression model. $\beta_{0}=$ intercept. $\beta_{1}=$ ith coefficient of xi $\mathrm{xi}=$ ith independent variable from total set of $\mathrm{q}$ variables. $\varepsilon_{\mathrm{i}}=$ random errors

The correlation and multiple linear regression analysis was conducted to investigate the relationship between TDS and other groundwater quality parameters. EC, $\mathrm{NO}_{3}^{-}, \mathrm{Cl}^{-}, \mathrm{Zn}^{2+}$ and $\mathrm{Fe}^{2+}$ constituents of the groundwater were considered as independent or predictor variables while TDS was considered as the dependent or criterion variable.

\section{RESULTS AND DISCUSSION}

The summary of the statistics of the groundwater quality parameters utilised for the correlation and multiple regression analysis is presented in Table 1. The degree of linear relationship between any pair of the hydrochemical parameters as computed by the Pearson's product moment correlation for the wet and dry seasons is presented in the correlation matrix shown in Tables 2 and 3, while in Table 4, the summary of the multiple linear regression for both seasons are presented.

As shown in Table 1, the concentration of TDS in the groundwater varied between 13 and $488 \mathrm{mg} / \mathrm{L}$ during the wet season and between 12.80 and $382 \mathrm{mg} / \mathrm{L}$ during the dry season. For Electrical Conductivity (EC), the values ranged between 26.00 and $712 \mu \mathrm{S} / \mathrm{cm}$ during the wet season and between 26.40 and $690 \mu \mathrm{S} / \mathrm{cm}$ during the dry season.

For $\mathrm{NO}_{3}{ }^{-}$the mean concentration was $2.67 \mathrm{mg} / \mathrm{L}$ during the wet season and $15.12 \mathrm{mg} / \mathrm{L}$ during the dry season. For $\mathrm{Zn}^{2+}, \mathrm{Cl}^{-}$and $\mathrm{Fe}^{2+}$, the mean concentration was of the order wet season >dry season, with $\mathrm{Zn}^{2+}$ recording a mean concentration of $3.43 \mathrm{mg} / \mathrm{L}$ during the wet season and $0.35 \mathrm{mg} / \mathrm{L}$ during the dry season. Mean $\mathrm{Cl}^{-}$concentration in the groundwater, was $121.27 \mathrm{mg} / \mathrm{L}$ and $161.33 \mathrm{mg} / \mathrm{L}$ for the wet and dry seasons, respectively. Wet season mean $\mathrm{Fe}^{2+}$ was $0.71 \mathrm{mg} / \mathrm{L}$ while it was $0.28 \mathrm{mg} / \mathrm{L}$ in the dry season.

As shown in Table 2, the correlation between TDS and other groundwater quality parameters around the dumpsites was positive, with a significantly high positive correlation exhibited between TDS and EC ( $\mathrm{r}$ $=0.976$ ) during the wet season. In the dry season, significantly high positive correlation was also recorded between TDS and EC, with $\mathrm{r}=0.969$.

For $\mathrm{NO}_{3}{ }^{-}$the degree of positive correlation with TDS ranged from weak $(\mathrm{r}=0.263)$ in the wet season to very weak $(r=0.039)$ in the dry season. Association between TDS and $\mathrm{Zn}^{2+}$, and TDS and $\mathrm{Fe}^{2+}$, was positive in the wet season but negative in the dry season. In the wet season, a weak positive correlation was established between TDS and $\mathrm{Zn}^{2+}$, while a very weak positive correlation was established between TDS and $\mathrm{Fe}^{2+}$. Association between TDS and $\mathrm{Zn}^{2+}$, in the dry season, was weak at $r=-0.210$, while the negative relationship between TDS and $\mathrm{Fe}^{2+}$ was moderate.

Furthermore, the $r$ value (0.976) between TDS and EC (Table 2) and the coefficient of determination $\left(\mathrm{r}^{2}\right.$ $=0.95$ ) indicate that 95 percent of the variability in TDS for the wet season can be attributed to the variability of the electrical conductivity of groundwater around the dumpsites. Similarly, the 0.969 correlation coefficient value for EC (Table 3), and the coefficient of determination $\left(\mathrm{r}^{2}=0.94\right)$ indicate that 94 percent of the variability in TDS during the dry season is due to the electrical conductivity of the groundwater, while 40 percent of

\section{IDOWU BALOGUN; OLUBUNMI ADEGUN}


the variability is attributable to $\mathrm{Cl}^{-}\left(\mathrm{r}=0.607 ; \mathrm{r}^{2}=\right.$ 0.40 )

From the summary of the multiple linear regression model for predicting TDS of the groundwater around the Solous dumpsites (Table 4), the linear regression equation for the wet and dry seasons, respectively are:

TDS $=-2.099+1.037 \mathrm{EC}-0.381 \mathrm{NO}_{3}{ }^{-}+0.337 \mathrm{Cl}^{-}-$ $0.006 \mathrm{Zn}^{2+}+0.112 \mathrm{Fe}^{2+}+\varepsilon_{\mathrm{i}}------(3)$

TDS $=0.547+0.852 \mathrm{EC}-0.069 \mathrm{NO}_{3}^{-}+0.187 \mathrm{Cl}^{-}-$ $0.039 \mathrm{Zn}^{2+}+0.030 \mathrm{Fe}^{2+}+\varepsilon_{\mathrm{i}}-------(4)$

As also shown in Table 4 and Equation 3, the positive sign of the beta coefficients and the t-values of EC, $\mathrm{Cl}^{-}$and $\mathrm{Fe}^{2+}$ indicate that a positive relationship exists between TDS and EC of the groundwater, as well as between TDS and $\mathrm{Cl}^{-}$and $\mathrm{Fe}^{2+}$ constituents of the groundwater for the wet season. The high absolute value of EC (19.819) and the small P-value (0.000) suggest that EC is very important variable in the prediction of the TDS of the groundwater. Furthermore, the adjusted $\mathrm{R}$ Square, which is the most useful measure of the success of the model when compared with the multiple $\mathrm{R}$ or $\mathrm{R}$ Square, indicate that the model accounts for 96.8 percent of the variance in the TDS concentration of the groundwater for the wet season.
For the dry season (Table 4 and Equation 4), a positive relationship was maintained between TDS and $\mathrm{EC}$, and between TDS and $\mathrm{Cl}^{-}$, while a negative relationship was maintained between TDS and other hydrochemical parameters $\left(\mathrm{NO}_{3}^{-}, \mathrm{Zn}^{2+}\right.$ and $\left.\mathrm{Fe}^{2+}\right)$. In predicting TDS for the wet season, the absolute value of $t$ and the small P-value of the EC emphasise the major impact of EC in predicting TDS of the groundwater for the season. With regards to the variability of TDS in the groundwater during the dry season, the model indicates that 93.9 percent of the variability is due to the combined influence of $\mathrm{EC}$, $\left(\mathrm{NO}_{3}{ }^{-}, \mathrm{Cl}^{-}, \mathrm{Zn}^{2+}\right.$ and $\mathrm{Fe}^{2+}$.

In conclusion, this study has shown that significant information can be obtained from groundwater quality data through the use of correlation and multiple linear regression statistical methods. Similarly, utilisation of the regression model's power of prediction and information on the degree of association between TDS and other hydrochemical parameters provided by the correlation analysis could assist in the implementation of seasonal groundwater quality monitoring programmes around the dumpsites.

Table 1: Statistical Summary of Groundwater Quality Parameters for the Vicinity of Solous 1 and Solous 2 Dumpsites

\begin{tabular}{|c|c|c|c|c|c|c|c|c|c|c|}
\hline \multirow{2}{*}{$\begin{array}{l}\text { Groundwater } \\
\text { Quality Parameter }\end{array}$} & \multicolumn{2}{|c|}{ Minimum } & \multicolumn{2}{|c|}{ Maximum } & \multicolumn{2}{|l|}{ Mean } & \multicolumn{2}{|c|}{ Standard Deviation } & \multicolumn{2}{|l|}{ Variance } \\
\hline & $\begin{array}{l}\text { Wet } \\
\text { Season }\end{array}$ & Dry Season & $\begin{array}{l}\text { Wet } \\
\text { Season }\end{array}$ & Dry Season & $\begin{array}{l}\text { Wet } \\
\text { Season }\end{array}$ & Dry Season & $\begin{array}{l}\text { Wet } \\
\text { Season }\end{array}$ & $\begin{array}{l}\text { Dry } \\
\text { Season }\end{array}$ & Wet Season & $\begin{array}{l}\text { Dry } \\
\text { Season }\end{array}$ \\
\hline TDS (mg/L) & 13.00 & 12.80 & 488.0 & 382.0 & 117.46 & 122.27 & 131.88 & 111.60 & 17393.51 & 12453.14 \\
\hline $\mathrm{EC}(\mu \mathrm{S} / \mathrm{cm})$ & 26.00 & 26.40 & 712.0 & 690.00 & 202.00 & 223.95 & 207.98 & 194.74 & 43257.28 & 37923.16 \\
\hline $\mathrm{Cl}^{-}(\mathrm{mg} / \mathrm{L})$ & 0.05 & 0.04 & 9.09 & 86.40 & 2.67 & 15.12 & 2.99 & 23.11 & 8.96 & 533.93 \\
\hline $\mathrm{NO}_{3}{ }^{-}(\mathrm{mg} / \mathrm{L})$ & 30.00 & 16.00 & 470.0 & 548.00 & 121.27 & 161.33 & 140.12 & 171.50 & 19632.92 & 29411.81 \\
\hline $\mathrm{Zn}^{2+}(\mathrm{mg} / \mathrm{L})$ & 1.10 & 0.12 & 10.30 & 0.72 & 3.43 & 0.35 & 2.73 & 0.20 & 7.48 & 0.04 \\
\hline $\mathrm{Fe}^{2+}(\mathrm{mg} / \mathrm{L})$ & 0.05 & 0.17 & 2.20 & 0.39 & 0.71 & 0.28 & 0.55 & 0.07 & 0.30 & 0.01 \\
\hline
\end{tabular}

Table 2: Correlation Matrix for Groundwater Quality Parameters in the Vicinity of Solous 1 and 2 Dumpsites for the Wet Season

\begin{tabular}{|l|l|l|l|l|l|l|}
\hline & TDS & $\mathrm{EC}$ & $\mathrm{NO}_{3}^{-}$ & $\mathrm{Cl}^{-}$ & $\mathrm{Zn}^{2+}$ & $\mathrm{Fe}^{2+}$ \\
\hline TDS & 1 & & & & & \\
\hline $\mathrm{EC}$ & 0.976 & 1 & & & & \\
\hline $\mathrm{NO}_{3}^{-}$ & 0.263 & 0.282 & 1 & & & \\
\hline $\mathrm{Cl}^{-}$ & 0.205 & 0.172 & $0.925^{* *}$ & 1 & & \\
\hline $\mathrm{Zn}^{2+}$ & 0.182 & 0.165 & $0.823^{* *}$ & $0.816^{* *}$ & 1 & \\
\hline $\mathrm{Fe}^{2+}$ & 0.02 & -0.097 & 0.397 & 0.415 & 0.492 & 1 \\
\hline
\end{tabular}

** Correlation is significant at the 0.01 level

\section{IDOWU BALOGUN; OLUBUNMI ADEGUN}


Table 3: Correlation Matrix for Groundwater Quality Parameters in the Vicinity of Solous 1 and 2 Dumpsites for the Dry Season

** Correlation is significant at the 0.01 level (2-tailed)

* Correlation is significant at the 0.05 level (2-tailed)

\begin{tabular}{|l|l|l|l|l|l|l|}
\hline & TDS & EC & $\mathrm{NO}_{3}{ }^{-}$ & $\mathrm{Cl}^{-}$ & $\mathrm{Zn}^{2+}$ & $\mathrm{Fe}^{2+}$ \\
\hline TDS & 1 & & & & & \\
\hline $\mathrm{EC}$ & $0.969^{* *}$ & 1 & & & & \\
\hline $\mathrm{NO}_{3}{ }^{-}$ & 0.039 & 0.022 & 1 & & & \\
\hline $\mathrm{Cl}^{-}$ & $0.607^{*}$ & $0.516^{*}$ & 0.470 & 1 & & \\
\hline $\mathrm{Zn}^{2+}$ & -0.210 & -0.181 & 0.268 & 0.023 & 1 & \\
\hline $\mathrm{Fe}^{2+}$ & -0.510 & -0.482 & -0.289 & -0.459 & 0.067 & 1 \\
\hline
\end{tabular}

Table 4: Regression Statistics for Predicting Total Dissolved Solids in Groundwater within Solous 1 and 2 Dumpsites Vicinity for the Wet and Dry Seasons

\begin{tabular}{|l|l|l|l|l|l|l|}
\hline \multirow{2}{*}{$\begin{array}{l}\text { Water Quality Independent/ } \\
\text { Predictor Variable }\end{array}$} & \multicolumn{2}{|l|}{ Beta Coefficients } & \multicolumn{2}{l|}{ t-Values } & \multicolumn{2}{l|}{ Significance of at 5\% level (P-values) } \\
\cline { 2 - 7 } & $\begin{array}{l}\text { Wet } \\
\text { Season }\end{array}$ & Dry Season & Wet Season & Dry Season & \multicolumn{2}{l}{$\begin{array}{l}\text { Wet } \\
\text { Season }\end{array}$} \\
\hline $\mathrm{EC}$ & 1.037 & 0.852 & 19.819 & 9.765 & 0.000 & 0.000 \\
\hline $\mathrm{NO}_{3}^{-}$ & -0.381 & -0.069 & -2.736 & 0.833 & 0.023 & 0.426 \\
\hline $\mathrm{Cl}^{-2+}$ & 0.337 & 0.187 & 2.543 & 2.027 & 0.032 & 0.073 \\
\hline $\mathrm{Zn}^{2+}$ & -0.006 & -0.039 & -0.063 & -0.562 & 0.951 & 0.588 \\
\hline $\mathrm{Fe}^{2+}$ & 0.112 & -0.030 & 2.010 & -0.374 & 0.075 & 0.717 \\
\hline Multiple R & & & -2.099 & 0.547 & & \\
\hline $\mathrm{R}$ Square & & & 0.990 & 0.980 & & \\
\hline Adjusted R Square & & 0.980 & 0.961 & & & \\
\hline Standard Error & & 0.968 & 0.939 & & & \\
\hline F-Test Statistics & & 23.48 & 27.59 & & \\
\hline Overall Significance & & 86.505 & 44.016 & & \\
\end{tabular}

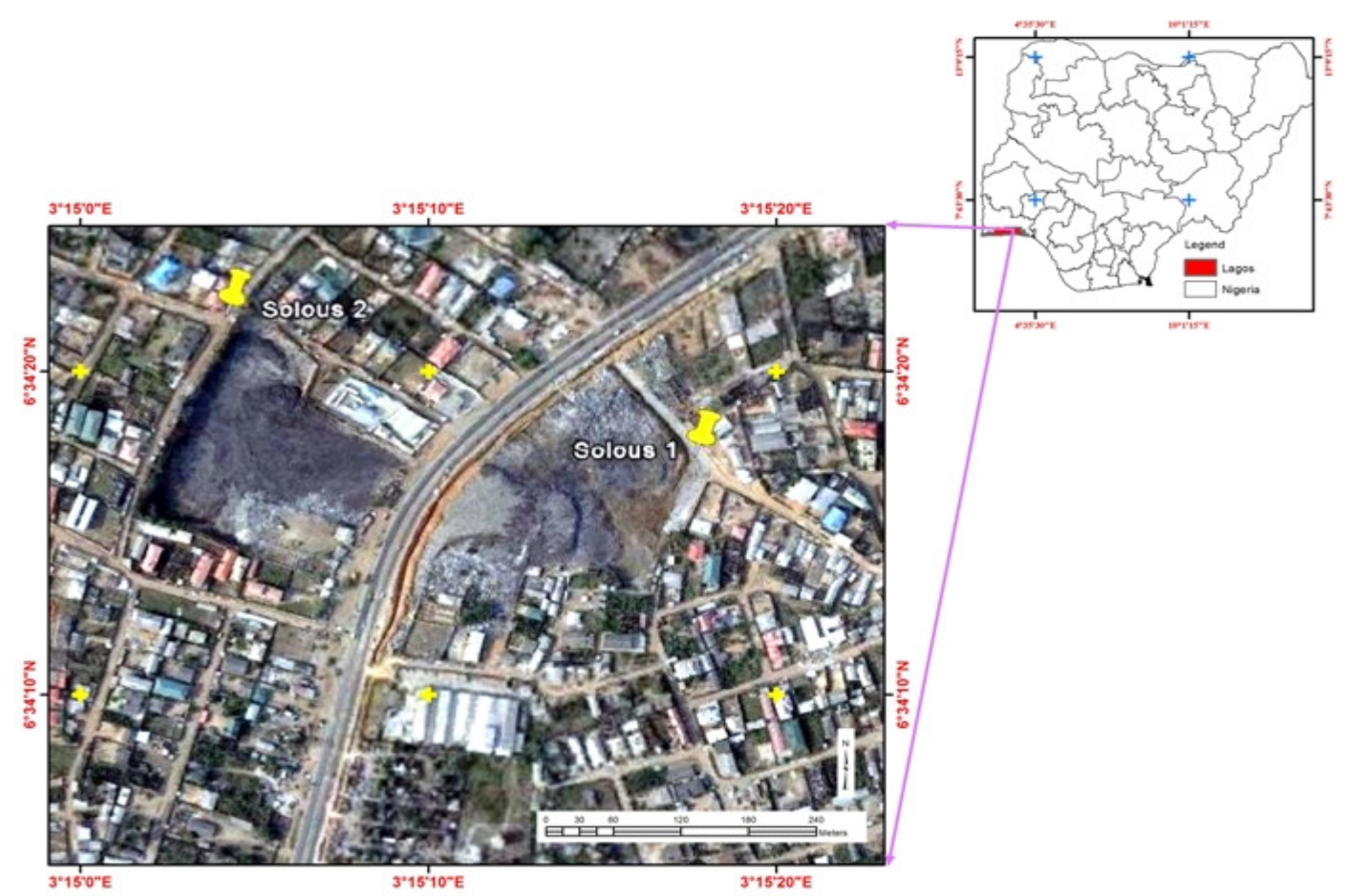

Fig.1: Solous 1 and 2 Dumpsites and Environs 


\section{REFERENCES}

Bjerg, P.L; Albrechsten, H.J; Kjelsen, P; Christensen, T.H. (2003). The Groundwater

Geochemistry of Waste Disposal Facilities. Treatise on geochemistry, 9, 579-612

Brace, N; Kemp, R; Snelger, R. (2009). SPSS for psychologists: A guide to data analysis using SPSS for windows ( $4^{\text {th }}$ edition). New York, Routlegde.

Chenini, I; Khemiri, S. (2009). Evaluation of groundwater quality using multiple linear

regression and structural equation modelling. International Journal of Science and

Technology, 6(3), 509-519. Retrieved from www.ijest.org/jufile?c2hvd1BERJ0ZNDU Colter, A; Mahler, R.L. (2006). Iron in drinking water. Retrieved from

www.cals.uidaho.edu/ed/comm/pdf/pnw/pnw589 .$\underline{\mathrm{pdf}}$
Raju, J.N. (2006). Seasonal evaluation of hydrogeochemical parameters using correlation regression analysis. Current Science, 91(6), 820826. Retrieved from www.ias.ac.in/currisci/sep2522006/820.pdf

World Health Organisation. (2006). Guidelines for drinking water quallity. (First Addendum $3^{\text {rd }}$ Edition. Vol 1, Recommendations). Retrieved from whqlibdoc.who.int/

Publications/2006/92415546964_eng.pdf. TDS and pH. (Undated). Safe Drinking Water Foundation. Retrieved from http://www.safewater.org.PDFS/resourcesknowt hefacts/TDSAND\%20PH.pdf 